\title{
As andanças de Zé: representações do povo nas revistas curitibanas de humor do início do século XX
}

\author{
The walkabouts of Zé: representations of people in the humor magazines \\ from the city of Curitiba in the beginning of the $20^{\text {th }}$ century.
}

Marilda Lopes Pinheiro Queluz

RESUMO

O objetivo deste texto é refletir sobre as representações do povo no humor gráfico curitibano do início do século XX, a partir da imagem do Zé Povo. O personagem Zé Povinho, criado pelo caricaturista português Rafael Bordalo Pinheiro, no final do século XIX, inspirou vários desenhistas brasileiros e ganhou inúmeras versões em todo país. Embora a figura de Zé Povo fosse uma tentativa de síntese do povo brasileiro, ele desfilou pelas revistas O Olho da Rua (1907-1911), A Carga! (1907), A Rolha (1908) e A Bomba (1913) apresentando múltiplas faces, evidenciando a pluralidade de olhares e a diversidade cultural da experiência urbana.

Palavras-Chave: Caricatura. Humor gráfico. Zé Povo.

ABSTRACT

The aim of this text is to reflect upon the representations of people in the graphic humor in Curitiba in the beginning of the $20^{\text {th }}$ century based on the character of Zé Povo. Zé Povinho, created by the Portuguese cartoonist Rafael Bordalo Pinheiro at the end of the nineteenth century, inspired many Brazilian cartoonists and won several versions throughout the country. Even though the character was an attempt to synthesize Brazilian people, it appeared in magazines such as O Olho da Rua ("Sacked", 1907-1911), A Carga! ("Cargo", 1907), A Rolha ("The Cork", 1908), and A Bomba ("The Bomb",1913) displaying multiple facets, putting on evidence the multitude of views and the cultural diversity of the urban experience. 


\title{
Introdução
}

Nas charges publicadas no início do século XX, em Curitiba, veiculadas pelas revistas $\mathrm{O}$ Olho da Rua, A Carga!, A Rolha e A Bomba1, entre as representações da cidade, transitam várias faces da população, que mesmo numa busca de síntese, como é o caso do Zé Povo, não constituem um quadro homogêneo. Nas quatro revistas estudadas, a presença do povo estava assegurada na preocupação com os tipos populares. São recorrentes as tentativas de estabelecer um personagem característico, pontuando pessoas e lugares bem típicos da cidade, como o pasteleiro, o jornalista, o agricultor, o funcionário público, o vendedor de vassouras, etc., que deveriam ser rapidamente reconhecidos, pela profissão, pelos trajes, pela voz, pelos gestos. Dentro dessa tendência, acalantava-se o desejo, herdado do século anterior, de encontrar a "identidade" brasileira, o símbolo do povo brasileiro.2

Ao definirem-se como revistas populares, elas procuram representar a opinião do povo, a voz do povo, o olhar do povo, a gestualidade do povo. Corporificam, presentificam esse povo na elaboração de personagens como Zé Povo, entre outros. Mas como se constrói essa presença, esse corpo que sente e conhece o cotidiano? Como essa testemunha da experiência urbana do início do século é mostrada? Qual o espaço criado para ele? Buscar algumas dessas respostas foi o objetivo deste texto.

De acordo com Fonseca (1999, p. 17),

\begin{abstract}
A caricatura é uma representação plástica ou gráfica de uma pessoa, tipo, ação ou ideia interpretada voluntariamente de forma distorcida sob seu aspecto ridículo ou grotesco. É um desenho que, pelo traço, pela seleção criteriosa de detalhes, acentua ou revela certos aspectos ridículos de uma pessoa ou de um fato. Na maioria dos casos, uma característica saliente é apanhada ou exagerada. Geralmente a caricatura é produzida tendo em vista a publicação e com destino a um público para quem o modelo original, pessoa ou acontecimento, é conhecido. (grifos nossos)
\end{abstract}

\footnotetext{
1 As charges analisadas nesta pesquisa foram divulgadas nas seguintes revistas: O Olho da Rua (1907-1911), A Carga! (1907), $A$ Rolha (1908) e $A$ Bomba (1913). A pesquisa foi feita com os exemplares do Museu Paranaense ( $A$ Rolha e $A$ Carga) e com os arquivos em microfilme da Biblioteca Pública do Paraná (O Olho da Rua e $A$ Bomba).

2 Em 1908 a revista Fon-Fon abriu um debate sobre a representação caricatural do brasileiro. Vários caricaturistas enviaram desenhos e opiniões. Do Índio de Ângelo Agostini, criado durante o Império, ao calunga com o cruzeiro do sul na camisa e calções listrados de verde e amarelo, criado por J. Carlos, na busca de um símbolo, Zé Povo prevaleceu, perdendo para o Jeca, na década de 20. In: Saliba, 1998 e 2002; Silva, 1987: p. 20-21 Ver também Herman Lima, História da Caricatura no Brasil.
} 
Já Garcia Canclini (1995, p.249) considera as caricaturas como um gênero híbrido por definição, destacando a maneira como são produzidas: "Elas são práticas que desde o seu nascimento ignoraram o conceito de coleção patrimonial. Lugares de intersecção entre o visual e o literário, o culto e o popular, elas trazem o artesanal para perto da produção industrial e da circulação em massa."

Para Rivers (1991, p.184), a caricatura não é uma entidade pré-existente, emoldurada por um contexto, mas está situada numa dimensão que interage com o processo histórico em que se constitui. Ela é dinâmica, sendo sempre reiterada e atualizada, como "algo que é continuamente produzido, e o qual é envolvido numa interação pessoal com seu contexto. Caricaturistas são influenciados pelo contexto tanto quanto tentam influenciar o mesmo."

Assumimos também a afirmação de Diana Donald (1996) de que é possível pensar as caricaturas como artefatos complexos que dão visibilidade às contradições das práticas culturais de uma dada época, não apenas como reflexo do social, mas ajudando a constituir e divulgar essa visibilidade.

Procuramos compreender o personagem Zé Povo através da análise discursiva das imagens, onde o conteúdo narrativo, a linguagem e o contexto histórico são considerados como uma unidade expressiva e dialógica, construída nas relações entre a materialidade do desenho, a organização da forma e os vários níveis de significação do texto. Mas as interpretações aqui propostas não negam, de forma alguma, o caráter sempre polissêmico do humor gráfico.

\section{O Zé Povinho português}

Ao estudar as caricaturas de Zé Povo, chegamos àquele que teria servido de modelo, o Zé Povinho, criado pelo caricaturista português Rafael Bordalo Pinheiro, em junho de 1875. Ramalho Ortigão, ao comentar o contexto no qual surgiu esse personagem, justifica:

Em Portugal, onde a vida da nação há tão pouco tempo ainda deixou de ser monopólio dos frades e dos capitães-mores, do clero e da Corte, onde o regime da discussão e o sistema de liberdade se iniciam apenas com um aprendizado de iniciativas contraditórias, a opinião popular acha-se por constituir. Bordalo Pinheiro teve de inventar arbitrariamente para seu uso a personagem simbólica do Zé Povinho, [...] (ORTIGÃO apud ARAUJO, 1996, p. 94) (grifos nossos). 
Rafael Bordalo Pinheiro (1846-1905) foi caricaturista, jornalista, pintor, gravador e ceramista. Veio ao Brasil em 1875 e assumiu a direção do jornal o Mosquito, além de realizar charges em Psit!!! e O Besouro. Em 1879, retornou a Portugal. Esteve ligado ao Grupo do Leão, onde teria sido influenciado pelo naturalismo português:

\begin{abstract}
Esses jovens pintores, de volta de seus estudos em Paris para Portugal, impregnados dos novos cânones naturalistas, redescobrem a luz da paisagem natal, seus campos, suas aldeias e suas praias, seus personagens e seus tipos populares, e essa liberdade e essencial para a eclosão de uma arte não mais submissa a sua representação acadêmica. Assim constrói-se um cenário que irá traduzir em novas formas cores e expressões, esse mundo português, mas nele os artistas do Grupo do Leão .fixarão ainda esses saloios e aldeões cuja representação idílica serve de imagem do povo, modelo mítico para a criação de uma identidade nacional, em meio ao desenvolvimento da modernidade cosmopolita em rápida expansão. (ARAÚJO, 1996, p. 19) (grifos nossos).
\end{abstract}

Simonetta Luz Afonso (apud ARAUJO, 1996, p. 15), fazendo uma comparação com Eça de Queiroz, ressalta: "O mesmo espírito de ironia desencantada, a mesma visão de um país doente, limitado pelo poder do rei e do clero e sugado por um Parlamento desacreditado, perpassam os desenhos amargos de Rafael Bordalo Pinheiro". Veremos que essa ideia do país como um corpo, como um organismo, estará presente nas charges.

Embora o enfoque deste estudo seja o Zé curitibano, pareceu-nos enriquecedor perceber como esses personagens mantêm um diálogo, um certo vínculo, através de correspondências e diferenças políticas e visuais. Para isso, escolhemos três momentos do Zé Povo português como um primeiro passo na tentativa de compreensão dos estados e das transformações que constroem o caminhar de Zé, servindo como contrapontos na complexidade do personagem brasileiro.

No portrait-charge de Zé Povinho (fig.1), publicado no Álbum das Glórias, sob o título de "O soberano", podemos observar algumas características recorrentes desse personagem. Comecemos comparando a imagem com um comentário da época:

Bordalo representa-o na sua obra tal como ele realmente é: ignorante, servil, ingênuo, bonacheirão, tomando o símbolo supremo da Albarda como síntese coletiva de todos os fenômenos administrativos, mais ou menos baseados no imposto, e representados ao seu espírito como outras tantas arbitrariedades de que ele é vítima, e nas quais se resumem todas as suas relações com o poder, com a comunidade, com o Estado, com o governo, com a polícia. civil, com a guarda municipal, com o recebedor da fazenda ou com o rei, porque para ele todos esses termos diversos são expressões sinônimas da mesma entidade 
misteriosa e onipotente que é a albarda [...] (ORTIGÃO apud ARAUJO, 1996, p.94).

Figura 1 - Bordalo Pinheiro. “O soberano” - Álbum das Glórias - 1882.

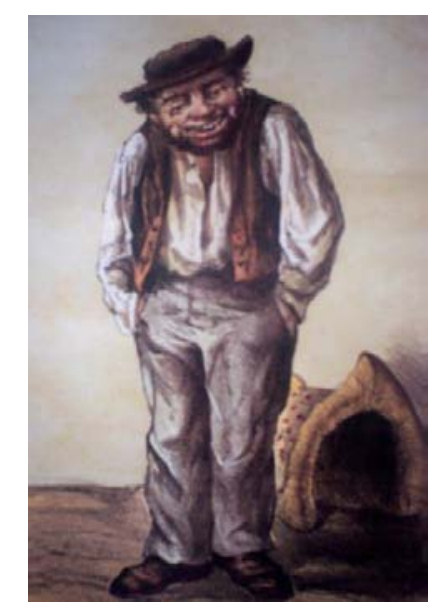

Fonte: Araujo (1996, p.108).

Temos aqui um "retrato" do povo. O enunciador apresenta Zé Povinho, de pé a nossa frente, encabulado, com as mãos nos bolsos, encurvado, com roupa comum de trabalho, de camponês, característica de seu ambiente cotidiano. Sorri, com jeito humilde, com a cabeça ligeiramente inclinada para a esquerda e para frente, num efeito de cumprimento. Nos trajes, na aparência (barba mal cuidada, dentes cariados, nariz e bochechas vermelhas) constrói-se a ideia de alguém simples, simpático, bonachão. Seu olhar é tímido, desviado, indireto. A albarda foi deixada de lado para o instante do desenho, para o encontro com alguém. Não a carrega como de costume, mas a coloca no chão, retirando o peso das costas, saindo da rotina.

Predomina a simplicidade, a naturalidade, o esboço. O improviso parece estar presente nos gestos, nos trajes, nos traços, nas cores, na textura, na postura. Cria-se um efeito de sentido de tentativa de proximidade, de subjetividade.

Esse tom de grosseiro é reiterado pelo desenho, como um rascunho, explorando o grafismo e a textura do lápis litográfico, deixando ver do que é feito e de que forma é feito. Funciona como uma metalinguagem, uma representação da representação. $O$ cenário transmite uma sensação de unidade entre o corpo e o objeto, enfatizada pelos tons terra que unem e harmonizam Zé com o ambiente, num fundo fechado, cujos limites são percebidos pela sombra da albarda projetada na parede. É um espaço restrito. 
O único elemento do cenário é a albarda, que se trata de uma "espécie de sela grosseira que serve para bestas de carga". Mas é também definido como "vexame, opressão, ou ainda, lograr, enganar grosseiramente, vestir-se mal, [...]" $O$ verbete albardeiro aparece como "mentiroso, enganador". Pelas vestes descobrimos que se trata de um saloio, termo usado para designar um "aldeão dos arredores de Lisboa, tido figurativamente como rústico, grosseiro, aldeão, matreiro, velhaco". (DICIONÁRIO CONTEMPORÂNEO DA LÍNGUA PORTUGUESA CALDAS AULETE, 1980).

A curva do corpo encolhido, unindo os ombros e a cabeça repete-se na curva da albarda. A inclinação do chapéu e do sorriso é paralela à inclinação da albarda. O ângulo da sela inclina-se para o lado, o mesmo da cabeça de Zé, apontando para ele. Essa reiteração de linhas curvas e formas sugere uma equivalência através de relações de semelhança: albarda (sela) e corpo criam o efeito de unidade, tecendo relações entre as cores, as linhas, a narrativa, entre a ideia de povo e soberano. A ironia está presente na discussão sobre as fronteiras entre o homem e o animal. Zé apresenta-se como besta de carga que precisa de uma albarda para ser montado, para transportar o peso que lhe é imposto. Há um dever fazer implícito: carregar, obedecer, aceitar, curvar-se ante o que se lhe apresenta (até ao leitor, nesse caso). Albarda e ele tomam-se a mesma coisa, uma carga, uma montaria. A metáfora da besta de carga para a imposição dos deveres e do espaço limitado de Zé realiza-se no desenho, no traço, na postura.

O título retoma o jogo visual, reconstruindo com ambiguidade e ironia o significado da palavra soberano. Questiona a autoridade, discute o conceito de soberania. Provoca um riso que faz pensar sobre a nobreza interior, sobre um povo que deveria ser soberano. Parece traduzir a imagem do que o povo poderia ou deveria ser, por aquilo que ele não é. ${ }^{3}$ Nas inversões propostas entrevê-se a visão liberal do povo como soberano.

Embora haja aqui um caráter combativo à monarquia portuguesa, Ribeiro alerta para o fato de que o conceito de povo das nações modernas carregam contradições e significados múltiplos. Apoiando-se nos argumentos de Fátima Ferreira, o autor lembra que "se durante o século XIX o povo ganhou protagonismo político, a associação com a plebe - o poviléu, a arraiamiúda - que já existia se manteve. Logo, o conceito de povo se constrói de forma ambígua, tendo um sentido 'positivo', quando se refere à soberania popular, e outro 'negativo', quando relacionado à plebe" (RIBEIRO, 2009, p.1045).

O contexto português da época foi marcado pelo período da Regeneração (1851-1890) momento de intensificação do comércio interno, especialmente a partir da segunda metade do século XIX, havendo um aumento das feiras e mercados, um avanço da industrialização, especialmente com a utilização do vapor; houve um grande afluxo de massas rurais aos grandes centros populacionais, um crescimento da dívida externa a partir de 1852; o fortalecimento da

3 Ao analisar o Zé Povo das páginas de Fon-Fon, Marcos Silva destaca a "estratégia de negatividade" para manter certa dose de ambiguidade em sua condição. Apresentado pelo que ele não era e gostaria de ser. (SILVA, 1987, p. 17). 
burguesia. O vinho, especialmente o duriense, foi um dos produtos fundamentais na economia de Portugal do século XIX. As revoluções de 1820 a 1851 criaram a monarquia liberal. O republicanismo cresceu a partir de 1890, quando o crescimento do proletariado urbano sofreu uma grande privação durante a recessão econômica, conduzindo à instauração da República portuguesa em 1910. (BIRMINGHAM, 1993)

Dialogando com a história, Bordalo Pinheiro propõe inversões que se entrelaçam no texto, na disposição e na proporção dos personagens, nas posturas e gestos. Na charge "O Dia de Reis" (fig.2), houve a seleção de uma data comemorativa para mostrar a situação do povo, o estado em que o povo tem se encontrado num dado tempo, revelar como todos os dias têm sido dia dos reis. Refere-se ao evento em que os reis foram visitar Jesus: são reis que trazem presentes, prestam homenagens a um rei maior. $\mathrm{O}$ enunciador utiliza-se de uma figura bíblica para revestir o tema da grandiosidade do povo. ${ }^{4}$ Mas, em contrapartida, vemos Zé Povo dormindo sob os pés da realeza. A homenagem é, assim, ironizada, invertida, reconstruída.

Figura 2 -Bordalo Pinheiro. "O Dia de Reis” - O Antonio Maria, 6/01/1881 .

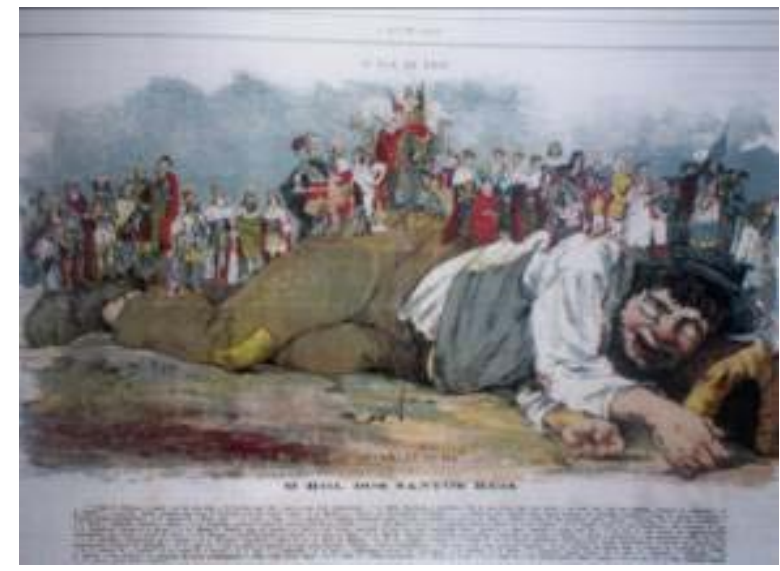

Fonte: Araujo, (1996, p.95).

Uma questão insere-se dentro da imagem, com letras mais finas, quase imperceptíveis entre as cores do chão: Levantar-se há? Pergunta pra quem? Quem pergunta? É uma interrogação jogada na terra, seguida de um silêncio que incomoda. É mais uma provocação ao leitor, instigando, talvez, a busca de uma resposta.

4 Esta estratégia foi bastante utilizada pelos caricaturistas curitibanos, unindo o sagrado e o profano para as críticas político-sociais. 
A ironia contamina todo o texto, numa crítica à realeza e às suas ambições, suas paixões, seus defeitos, sua proximidade com a igreja. Os reis aparecem como listagem, classificados em ordem temporal, enfileirados. $O$ povo é identificado, personalizado, reconhecido, unificado na imagem de Zé enquanto a realeza é vista como uma sequência numérica. Os reis são conhecidos pelo número, mas o povo é reconhecido pelo nome, pela intimidade do apelido, pelo Zé inscrito na borda da camisa, exatamente no centro geométrico da construção da imagem.

A composição é dividida pela figura centralizada de Zé. A sinuosidade do seu corpo divide a imagem ao meio, definindo o horizonte de nosso olhar. A parte de baixo é ocupada pelo corpo e a terra - onde há um vazio, uma monotonia dos tons, quebrada pela mancha vermelha à esquerda (sangue derramado) que se prolonga até a pergunta, acabando no "L", exatamente onde a indagação ao futuro começa.

O corpo é colocado como montanha, alicerce, dominando a paisagem. Ele se estende como uma linha do tempo, marcada pela transição das dinastias, pelo peso dos fatos, dos atos dos reis. Os pés trazem o passado e a cabeça sustenta o presente. Isso é reforçado pela variação do espaço topológico, em que os pés, colocados mais ao fundo da cena, afastam-se do observador, numa ligeira inclinação da perspectiva, enquanto a cabeça e as mãos aproximam-se. Nosso olhar é levado para a direita, apontando para um futuro incerto, em desequilíbrio, instável.

Pode-se pensar em uma reescrita da história, inscrita no corpo do povo. Corpo como conhecimento. Corpo marcado, corpo presente. Corpo como o meio pelo qual percebemos o mundo, para o qual encontramos expressão para o mundo. É através dele que estamos situados no mundo e, ao mesmo tempo, temos a perspectiva do mundo. O corpo vivido é uma maneira de estar com os outros e estar situado numa condição social e na história. (MEARLEAU-PONTY, p. 185-213).

Essa charge permite discutir, também, a questão do povo como corpo social.

No século XIX, a metáfora do corpo orgânico percorre o discurso dos médicos sanitaristas, assim como de outros homens cultos do período, na representação da sociedade. Pensado como um organismo vivo, o corpo social segundo esta construção imaginária deveria ser protegido, cuidado e assepsiado através de inúmeros métodos e mesmo de cirurgias que extirpassem suas partes doentias, seus cancros e tumores. (RAGO, 1985, p. 167).

Mas o interessante aqui é notar como até essa ideia é ironizada. O corpo é visto como memória, mas relativizada, dinâmica, em fragmentos que se reagrupam, formando novas imagens a cada olhar. 
Zé faz a concomitância entre passado e futuro. Instauram-se tempos que se conjugam e convivem. A data comemorativa remete ao passado longínquo (nascimento de Cristo), reatualizado no passado próximo (final do século XIX) e na contemporaneidade do leitor. Zé sustenta a monarquia no tempo e no espaço.

Considerando-se os efeitos cromáticos, predominam os azuis cinzentos e esverdeados, cores frias, pontuadas pelos vermelhos dos mantos reais. A grande mancha branca, formada pela manga da camisa de Zé, remete ao branco das nuvens, manchas que se diluem no branco da página, deixando aberto o espaço. Há uma margem limítrofe da história (dados escritos), mas não da ação (imagem).

No canto inferior esquerdo vemos uma mancha vermelha, paralela às pernas de Zé, onde o povo é presentificado também pelo vermelho delimitado, como o sangue misturado à terra, numa das associações possíveis. Dessa maneira, o sangue - guerra, luta, sacrifício, está no mesmo plano, embora em lados opostos, das mãos - trabalho, esforço. O sacrifício do povo é caracterizado nestes dois aspectos, ao longo do tempo. O tempo imprime-se na matéria, na terra, no corpo.

Zé encontra-se totalmente ligado à terra, enquanto a nobreza não toca o chão. Os reis ajoelham-se, sentam, fazem pose e olham quase todos, para a direita. Eles possuem movimento, ritmo, em oposição à estabilidade, permanência do povo. Zé dorme de lado, de frente para o enunciatário, para o leitor, aquele que olha o povo dormindo. Dorme ao invés de agir? A cabeça recostada à albarda traz uma nova inversão: a representação do povo como que acima dos problemas, esquecido deles, em estado de suspensão, rearticulando seu papel na sociedade.

A desproporção entre os personagens lembra-nos as aventuras de Gulliver em Lilliput. O gigante adormecido de Swift que, ao acordar desfaz as amarras, livra-se das cordas e estacas colocadas ao lado de seu corpo, e passa a aprender uma nova língua, uma nova cultura, novas leis e hábitos, deslocando-se de seu ponto de vista (social e visual, cognitivo e perceptivo). A grandiosidade do povo, sua real importância é construída pela inversão do olhar, numa historia às avessas, onde não se fala dos grandes reis da história e o povo, mas do grande povo e os "reizinhos".

Segundo Sousa (2002, p.38), em muitas ocasiões Bordalo Pinheiro sonhou com o Zé se levantando e derrubando "as alforjas (símbolo caricatural da exploração)".

Acordar e levantar significa derrubar a monarquia. A disjunção entre o Zé e os reis implica uma transformação. A performance a ser desempenhada pelo povo é erguer-se, inverter a ordem. O enunciador trabalha com a provocação, investindo na dúvida sobre a competência do povo e da monarquia ao mesmo tempo. O povo conseguirá se levantar? A realeza irá se equilibrar? Zé possui a capacidade para isso? De quem ele depende para poder agir? O enunciatário pode ou deve acordá-lo? Neste caso, o enunciatário não é povo, está além dele. Cabe ao enunciatário um fazer. 
O povo constitui-se como um objeto de valor para a história, um sujeito atuante, capaz de transformações, como base da sustentação da realeza, como manutenção do equilíbrio, definido pela negação - não poder, não saber; não querer. $O$ enunciatário é levado a crer que vale à pena acordá-lo, ressaltando-se sua importância para a transformação política.

Em Actualidade (fig.3), Bordalo Pinheiro utilizou-se de uma imagem bastante complexa para criticar a sociedade de seu tempo.

Figura 3 -Bordalo Pinheiro. “A indiferença mascara a miséria.” - A Paródia, 26/01/1901

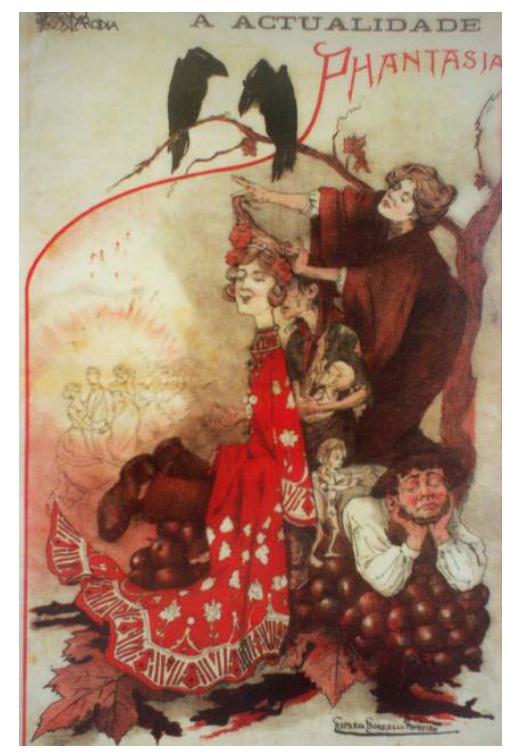

Fonte: Araujo (1996, p. 115).

Vemos Zé em relação com diversos setores da sociedade. Ao centro, formando uma vertical que divide a cena, vemos a figura feminina de vermelho, caracterizada pela elegância, pela ausência de volume, quase incorpórea, com a sinuosidade do Art Nouveau, quase uma estampa, anunciando o baile. O desenho do manto assemelha-se ao recorte da folha da parreira. $́$ É como uma máscara, escondendo a tragédia, o sofrimento, a fome. O vermelho do manto prolonga-se, formando uma curva que envolve o baile, mas não se fecha. É como um halo de luz, uma aura vermelha, que envolve aqueles que dançam, esvanecendo-se no ar. Esta figura central estabelece um limite, colocando à esquerda o efeito de superficialidade, a festa, a leveza, a riqueza, as linhas, e à direita a pobreza, o trabalho, a marginalidade, a monotonia da vida, a monocromia, o volume. Marca-se uma distância entre dois mundos, acentuada pela perspectiva e pela diferença de tratamento gráfico. A nobreza é vista em seu contorno, e o volume e o peso é dado aos pobres.

A mãe pobre, ocupando o espaço limitado entre as outras duas mulheres, tem a face oculta pela beleza, pela riqueza. Vemos sua mão estendida, mendigando, formando um gancho que é reiterado pela forma do manto vermelho, ambos apontando para a mesma direção, o lugar da 
dança. Há um jogo de sobreposições, um dinamismo de curvas entrelaçadas, uma rede de gestos formada pelos braços da mãe, pelos braços da que penteia, pelos braços do garotinho, pelo corpo do Zé. Esses corpos que se cruzam, tecem uma trama intrincada, numa interdependência entre traços, personagens, ações. No campo cromático essas associações são construídas pela sutileza dos tons: criam uma unidade entre o tronco, o corpo da mulher que penteia o cabelo da outra, o lenço que envolve a cabeça da mulher com a criança ao colo, o chapéu e as calças de Zé, as uvas, tudo com o mesmo tratamento gráfico. Torna-os parte da mesma realidade - a da produção das uvas e do vinho - estabelecendo uma relação de contiguidade, uma relação metonímica.

A pobreza é acentuada especialmente pelos corpos das crianças raquíticas, pela expressão de dor, pelas três faces sofridas (mãe e crianças) em oposição às três faces serenas (as bochechas rosadas das duas mulheres e do Zé). Um menino cutuca as costas de Zé, enquanto este se mantém imóvel, dá as costas à pobreza. Zé está deitado sobre o gigantesco cacho de uvas, com a cabeça apoiada nas mãos, os olhos fechados, num gesto de indiferença? A composição é marcada pelas desproporções entre Zé e as uvas gigantes e entre o corpo de Zé e o da criança que o toca, construindo-se graficamente a desproporção / desigualdade social. As uvas aparecem como base, deixando manchas do vermelho escuro ao claro, dando margem a uma associação entre vinho e sangue. A uva sustenta o Zé, que, por sua vez, carrega, sustenta tudo às suas costas.

No enunciado verbal, a fantasia aparece em vermelho, numa letra trabalhada, apontando para baixo, diminuindo no final da palavra, contrastando com o preto das letras tipográficas de Actualidade e da frase. A palavra fantasia é quase manuscrita enquanto as outras são técnicas, mecânicas, padronizadas. $O$ galho da árvore (a videira) entra e sai da fantasia, criando um elo com a realidade. Sugere-se gráfica e cromaticamente que o vinho faz parte da realidade do trabalho, da realidade das festas, dos bailes. Desenvolve-se uma articulação entre espaços - aqui (no trabalho, na terra, na realidade) e lá (no baile, na festa, na fantasia). Vermelho é a cor do vinho, cor do sangue, cor da fantasia, do manto, da linha que envolve toda a cena, emoldura a realidade, mas não se fecha, abrindo-se para a atualidade, para o espaço da revista, deixando no ar uma interrogação: indiferença de quem? Dos ricos? Do Zé Povinho? Do leitor? Os recursos gráficos falam da distância e dos contatos entre esses mundos.

O enunciador trabalha com a sedução da beleza, da riqueza, da juventude, dos frutos, do aroma e sabor do vinho, da dança. Todos os sentidos são convocados na construção dessa imagem.

Nesta narrativa há uma provocação, um querer fazer e dever fazer. Ao denunciar a indiferença social, presente no rosto de Zé, o enunciador duvida de sua competência e transfere a responsabilidade para o leitor, propondo-lhe uma ação a ser realizada: novamente é preciso abrir os olhos, acordar o povo, realizar uma transformação social. 
Estas caricaturas de Bordalo Pinheiro trazem um riso provocativo, carregado de amargura. A presença do povo é constituída como força social, como viabilidade de futuros programas políticos. A ironia, a ambiguidade, o estranhamento, rearticulam sua posição na sociedade.

O enunciador faz ver ao enunciatário que a história e a sociedade podem ser/ ter um futuro diferente. Propõe uma mudança de paradigmas. Parece sugerir que a competência para tal não está no povo, mas naquele que o observa, que o conhece, aquele que doará essa competência, abrindo-lhe os olhos, acordando-o.

Nestas três charges, ao Zé Povo não é dada a voz, mas sua presença é marcante. Zé está sempre dentro do campo de ação, embora dormindo, de olhos fechados, com as mãos nos bolsos. Essa imobilidade, essa passividade de Zé Povinho gera uma expectativa, uma busca, um inconformismo. $O$ distanciamento entre o narrador e o Zé pede um destinatário que não seja o povo propriamente, mas uma classe mais consciente, mais elitizada, acima do povo, como o narrador, por exemplo. Constrói-se, assim, um discurso sobre o povo, mas não há identificação com aquele de quem se fala, mas com aquele que fala.

\section{Zé Povo em Curitiba}

Com o advento da República, o Brasil traçou a modernização do país na implantação de reformas urbanas e de inovações técnicas (ferrovias, telégrafos, telefones, gramofones, luz elétrica, bondes elétricos, cinematógrafos, litografia, zincografia, fotografia, novos processos de produção gráfica, por exemplo), na participação em Exposições Universais, nas novas percepções do espaço e do tempo, marcadas pelo ritmo da fábrica, da uniformidade e padronização das máquinas. Foi uma modernização conservadora, deixando a grande maioria da população à margem dos benefícios. Símbolo ou caricatura, sisuda ou cômica, de qualquer forma, a representação do país passava forçosamente pelos caminhos da inversão e recriação de sentidos, pelo jogo dialógico e tenso entre o real parodiado e a representação paródia. (SALIBA, 1998, p. 310).

A caricatura desse período, de um modo geral, voltou-se para a cidade, para as pessoas que nela viviam /transitavam, reciclando e contaminando-se dos discursos da ciência, da arte, da publicidade, da moda, do design gráfico, do teatro, da imprensa, etc, ajudando a reelaborar o sentido da experiência urbana. A representação do povo dá-se como modos de presença: as charges aparecem como flagrantes das ruas, da vida de personagens cotidianos.

Em meio à heterogeneidade e complexidade dessa população que desfilava pelas páginas das revistas, destaca-se a figura de Zé Povo que foi retomada e reelaborada por muitos 
caricaturistas brasileiros. ${ }^{5}$ Consideraremos proximidades e distanciamentos entre o Zé Povinho de Bordalo Pinheiro e os Zés curitibanos, em suas relações com o poder, com a sociedade, com suas próprias esperanças e anseios. São muitas as aparições do Zé Povo nas charges sobre as reformas da cidade (o calçamento, o encanamento) e sobre os políticos, valendo à pena propor alguns outros olhares para perceber as várias construções deste personagem.

Durante as reformas urbanas feitas na capital paranaense, as obras públicas foram o principal alvo das críticas mordazes dos caricaturistas. É como se a luta pelo exercício da cidadania fosse mais contundente nas reflexões sobre as práticas cotidianas. Na figura 4, Zé aparece sendo espremido pela senhora (em cuja barra do vestido lê-se "empresa de saneamento"), vertendo suor e lágrimas, numa cena grotesca. $O$ povo é mostrado enquanto corpo retorcido, esmagado, torturado, revirado do avesso, com as partes baixas ameaçadas, vomitando dinheiro, com os pés saindo dos limites do desenho. $\mathrm{O}$ desvio das verbas públicas e a má administração das obras são tratados nos limites da cidade, nos limites da imagem, nos limites da dor. Na enunciação verbal o povo é reduzido, tratado por seu diminutivo - "Zezinho".

Figura 4 - Heronio - A Carga! n. 9 - 04/01/1908

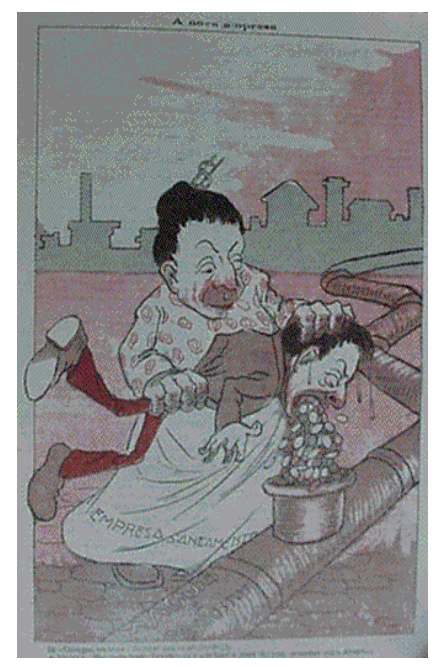

Zé - Devagar, madama; devagar que eu arrebento!!..

A Megera - Não tenha medo, Zezinho; eu hei de fazer a cousa tão bem, ou melhor que o Alvaro... Fonte: Hêronio (1908).

Em relação ao calçamento da cidade, os paralelepípedos tornam-se obstáculos para Zé chegar em casa, para entrar na cena.(Fig.5) Ele observa o quadro em que a cidade se encontra, com os pés tocando a linha entre a realidade das ruas e a da mídia impressa. A metalinguagem amplia o diálogo com a imprensa e reforça a ambiguidade da "opinião pública", essa autoridade

5 Sobre a análise do Zé Povo na revista Fon-Fon ver o livro de Marcos Silva, Caricata República. 
construída, um sujeito oculto que remete à maioria da população, à imprensa e a ninguém ao mesmo tempo. É uma "instância testemunha que assiste ao espetáculo e interpreta a sua significação, seja por conta própria, seja, mais geralmente, para um público situado num terceiro plano". (LANDOWSKI, p.22). Zé situa-se, aqui, como um porta-voz das angústias da população, destituído de poder.

Figura 5 - "Zelador de Curitiba” - O Olho da Rua, n.9, 14/10/1911

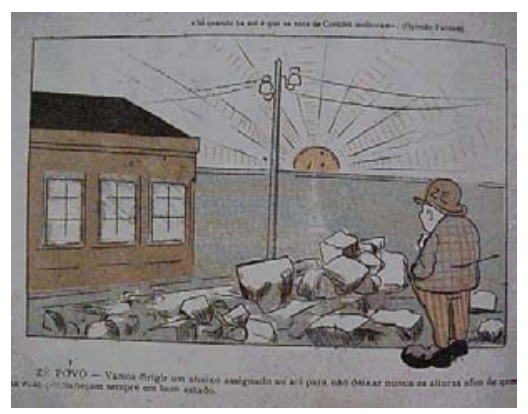

Só quando há sol é que as ruas de Curitiba melhoram (Opinião Pública)

ZÉ POVO - Vamos dirigir um abaixo-assinado ao sol para não deixar nunca as alturas a fim de que as ruas permaneçam sempre em bom estado.

A descrença no progresso acentua-se quando Zé coloca-se fora da cena, no plano da revista, do lado do leitor, da realidade diária, duvidando da modernização dos bondes.

Figura 6 -"Bondes elétricos" - O Olho da Rua n.9 - 14/10/1911.

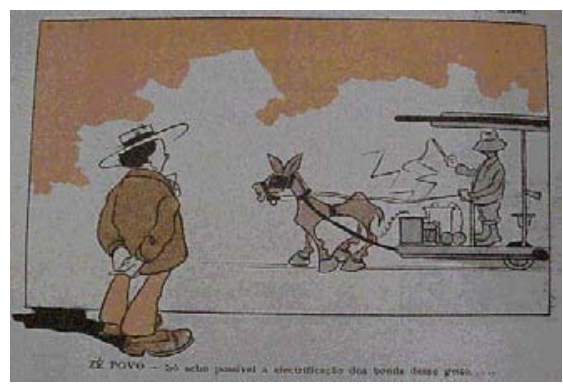

ZÉ POVO - Só acho possível a eletrificação dos bondes desse jeito.

Zé em muitas imagens esteve presente como um objeto inanimado, útil e decorativo, fazendo parte do gabinete oficial, como é o caso das figuras 7 e 8 . 
Figura 7 - "Preparativos". A Carga! n. 7 -7/12/1907.

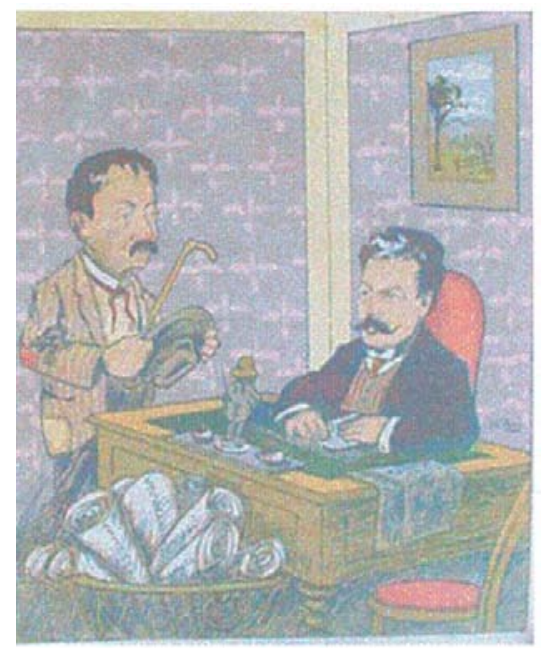

Zé - Está V. Excelência a parafusar com quantos paus se faz uma canoa?

João Cândido - Tal qual. Com uma diferença, porém, em vez de canoa é nau: estou aqui a parafusar sobre a equipagem e mais coisas da nau do Estado, que em breve vou dirigir

Zé - Está nisso todo êxito da derrota. Que o pessoal seja turuna ${ }^{6}$ e ... se houver borrasca que o leme não trema, e deixe correr o barco.)

Fonte: Herônio (1907).

A representação do povo nas decisões políticas é tratada aqui de maneira bem intrigante e complexa. A construção de Zé Povo como peça importante para o Estado é reforçada de várias maneiras. Há uma dupla presença de Zé - como objeto e pessoalmente - por quê? São duas funções, duas possibilidades de ação, dois modos de se colocar em cena. Simultaneidades espaciais e temporais - a presença constante e a presença fortuita, eventual. Zé aparece como estatueta, objeto miniaturizado, uma peça do tinteiro - o suporte para a pena - num efeito de sentido de que as decisões dependem, passam pelas mãos dele, quase um aval para as assinaturas: estar na mesa, estar no gabinete, segurar a pena que assinará os atos do governo, as decisões futuras, interferindo de algum modo no futuro.

Nos papéis enrolados lê-se empenho ${ }^{7}$, velhacaria, mamata... planos que estão em destaque na desproporção e no traço detalhado da cesta de lixo. Outro objeto importante nesse cenário é a revista $A$ Carga! na lateral da mesa, por baixo, discreta. Colocar uma leitura crítica e irreverente próxima ao governante é uma metalinguagem que leva a novos deslocamentos: o gabinete está dentro da revista, que está dentro do gabinete - interação, inter-relação, refletindo o mundo fora

\footnotetext{
6 Forte, poderoso, valentão

7 Empenho, neste caso, é tanto no sentido de pistolão, quanto de uma verba destinada a certa despesa pré-estabelecida no orçamento de uma repartição pública.
} 
das páginas. A revista dentro da revista, dentro das charges nos fala do papel da revista, da imprensa. É outra forma de presença do povo, ou daqueles que se dizem representantes dos interesses do povo. Os destinos do Paraná estão colocados no diálogo, na metáfora da nau (ou canoa?) a deriva. Quem deve estar presente ao leme? Quem deve ser turuna - o povo? A expressão invertida "Êxito da derrota", unindo antônimos, parece sublinhar a indefinição dos rumos políticos Estado.

Em outro momento político, é também como objeto decorativo que Zé foi colocado próximo ao poder (fig.8).

Figura 8 - "Felicitações " - A Carga! n. 9 04/01/1908

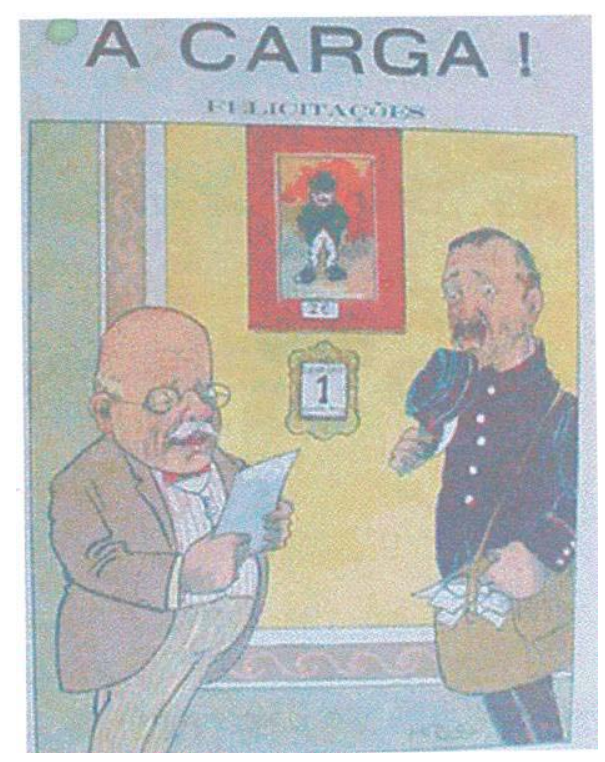

Coronel Monteiro (todo risonho) - São uns pândegos esses rapazes d'a Carga! O ano inteiro eles chasqueamme a valer e por fim felicitam-me nestes termos:

Nhô Quinco Monteiro, destas Plagas, ora chefe mor Viemos dar-lhe boas festas Nestas quadrinhas de cor Que o novo ano lhe seja Gostoso como torresmos, Nele alcance o que deseja ... São os votos que fazemos.)

Fonte: Herônio (1908).

O personagem torna-se um quadro na parede, no lugar de um retrato oficial - uma inversão de imagens e homenagens. Ocupa um espaço dentro do gabinete, junto ao calendário, para ser percebido diariamente. Trata-se de uma outra presença constante. Aparece de corpo inteiro, com as mãos para trás, num gesto de alguém que observa tudo. Seu destaque na parede é ampliado pelo vermelho e pela centralização. A placa com seu nome, como alguém importante uma presença nítida a ser lembrada - torna-se ambígua, pois o Zé é também decoração, está pendurado, emoldurado. Há uma superposição de molduras (a revista que serve de moldura para o gabinete, a moldura da parede, a do calendário, a do quadro), num jogo de enquadramentos que questiona as fronteiras, brinca com as possibilidades de estar dentro e fora. Aqui vemos 
novamente a referência à própria revista, pois a primeira edição de 1908 traz uma capa onde se vê a reação de Monteiro a uma mensagem enviada pela própria revista. Nas felicitações enviadas pela revista $A$ Carga! ao Presidente de Estado há uma forma de cobrança, uma provocação, uma maneira de fazer lembrar que estarão presentes durante todo o ano. Cria-se um efeito de que somos testemunhas, invadimos o escritório, ficamos surpresos como o carteiro, ele mesmo um trabalhador, também representando o povo. Todos observam o governante: a revista, o Zé, o leitor. A revista apresenta-se como estando perto do Zé e das autoridades, insinuando o papel da imprensa. Assim como o Zé, ela também acompanha, observa tudo o que acontece durante o ano todo. Sua arma é a ironia e o inesperado.

Em muitas situações Zé tomou a frente e marcou sua presença pela irreverência, mesmo numa visita oficial como por ocasião da visita do estadista francês Doumer a Curitiba (fig.9).

Figura 9 - "Dernier coup de main" - A Carga! n. 4 -03/10/1907

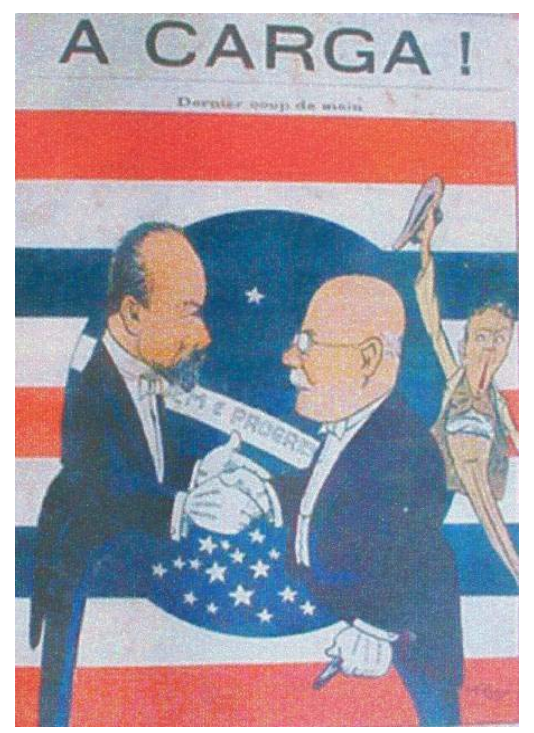

Doumer - Monsieur lê president Montero. Je suis infinitement enchante, plein de satisfation a mon depart du Paraná! Tout ce que j’ai vu ici, dans cette pays adorable, me retera toujours au cour!

Monteiro - Oh! Oh! Monsieur Doumer. Trés merci, trés merci. La chuve malheureusement, vous a empate touts les notres preciosidades naturals: l'avance, lê trem especiale, l'arc triunfale, le cortege ecolier, le banquete, le...le...le... mate chimarrone, le churrasque...e d'outre choses naturals. Au revoir, monsieur Doumier. Lembrance a monsieur Falieres. Zé - Viva monssui Doumer e monssui Monteró!!...) Fonte: Herônio (1907).

No último instante, Zé se faz presente. Interfere, interrompe, joga-se na foto oficial. Traz para a formalidade do gesto diplomático, o "viva" popular, a fala carregada de ironias e da pronúncia afrancesada. A ação caracteriza-se pelo exagero, pela tensão do corpo todo em curva, em desequilíbrio, pela forte expressão facial, como um grito que invade e rouba a cena. Insinua- 
se na paisagem/ inscreve-se na bandeira. Desorganiza a oficialidade do ato. Está dentro e à margem ao mesmo tempo. A bandeira ao fundo é uma fusão das bandeiras do Brasil e da França, sendo que o azul e o branco da nossa bandeira são predominantes e contaminam as roupas a rigor. O cumprimento de mãos reitera / duplica a faixa de ordem e progresso, unindo-os. A sátira às cerimônias oficiais repete-se no diálogo, onde a natureza (chuva) é culpada por prejudicar a mistura entre os avanços da cidade "civilizada", "moderna" (trem, arcos) e as tradições do sul (mate, chimarrão, churrasco).

Outras vezes, Zé procurou interferir diretamente nas decisões econômicas, como no caso das subvenções (fig. 10). O Estado é representado como uma máquina, semelhante a uma máquina de torrar café, mas que torra dinheiro (arame). Zé tenta impedir seu funcionamento, mas encontra-se numa espécie de ciclo contínuo do qual faz parte e, ao mesmo tempo está fora.

Figura 10 - A Carga! n. 2 -27/08/1907

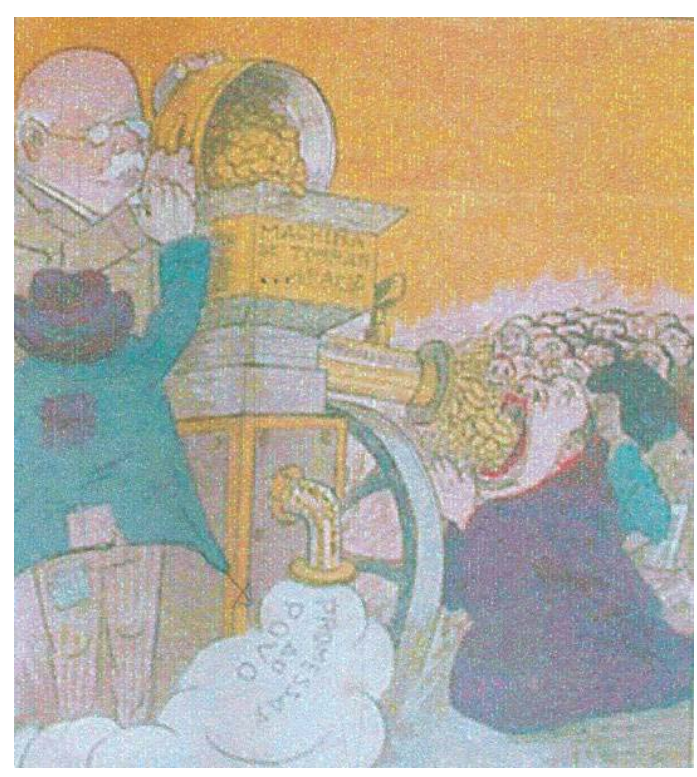

Zé - assustadíssimo - Devagar, coronel, devagar que isto não é nosso... e a máquina pode entupir ... Coronel Monteiro - Deixe-se de conversas fiadas, seu Zé, pois não vê que este pessoal está faminto e que é preciso matar-lhe a fome.

Zé - Mas não assim, com esta franqueza; nem todos precisam. É verdade que muitos merecem o dobro dessas subvenções que mais nada são para eles que um justo prêmio aos seus esforços, mas outros, coronel, outros metidos num saco e arremessados ao rio Ivo, só se perderia o saco, acredite.

Coronel - você é o único que está com essas reclamações. Este pessoal precisa, amigo Zé; são todos bons patriotas, amigos íntimos do Paraná e do povoamento do solo.

Zé - Patriotas parasitas; amigos do Paraná só no estômago e venha a nós - uns magnatas é o que são. Se eu reclamo é por ver meu rico arame, meu suor esbanjado tão inutilmente.)

Fonte: Herônio (1907).

As "promessas ao povo" saem por um cano de escape ("válvula de segurança"), viram fumaça, numa curva aos pés do Zé que se prolonga na curva do paletó e retorna para a fumaça. 
Existe uma relação entre esse movimento e a curva para cima, formada pelo braço e o ombro, e pela aba do chapéu, em oposição às outras curvas do desenho. São movimentos contrários, mas que criam um dinamismo que envolve Zé e o governador. Eles estão do mesmo lado, paralelos à máquina- ambos a realimentam? Zé encontra-se numa vertical, acima dos demais, acima das promessas, apenas abaixo do presidente do Estado. Ele está do lado do poder, de costas, com sua mão ao alcance do outro, a um instante de impedi-lo. As pessoas ajoelhadas e o destaque para o padre em primeiro plano reforçam visualmente a crítica do diálogo, atacando simultaneamente o sistema administrativo e a participação da igreja. Há uma associação entre as formas circulares: a cabeça de Monteiro, a roda, assim como o caldeirão e a grande boca - peças chaves para engolir dinheiro - imagem forte e grotesca para a má utilização do dinheiro público. O predomínio geral do amarelo - a cor do dinheiro - só é quebrado pelo verde do paletó de Zé e o vestido da professora, além da batina. $O$ centro da composição é a máquina - mais exatamente o cano por onde o dinheiro jorra - e nosso olhar é constantemente desviado de um lado a outro, da possibilidade de ação do Zé à realidade dos "patriotas/ parasitas".

Em alguns casos, a impossibilidade de agir diante da má administração do Estado foi mais enfatizada (fig.11). Essa relação de dependência foi construída na associação das finanças a um corpo enfraquecido, definhando. A economia foi tratada como uma doença cujo remédio traz mais efeitos colaterais do que benefícios. "As Finanças" e Zé se assemelham fisicamente, carentes de saúde e de recursos, ambos destacados pelo uso do vermelho (cobertor e colete). Zé é mostrado retorcido, desengonçado, magro, maltrapilho. Já o político é colocado acima de todos, como o anjo protetor, com os braços abertos em cruz.

Figura 11 - A Rolha n. 17 -17/09/1908.

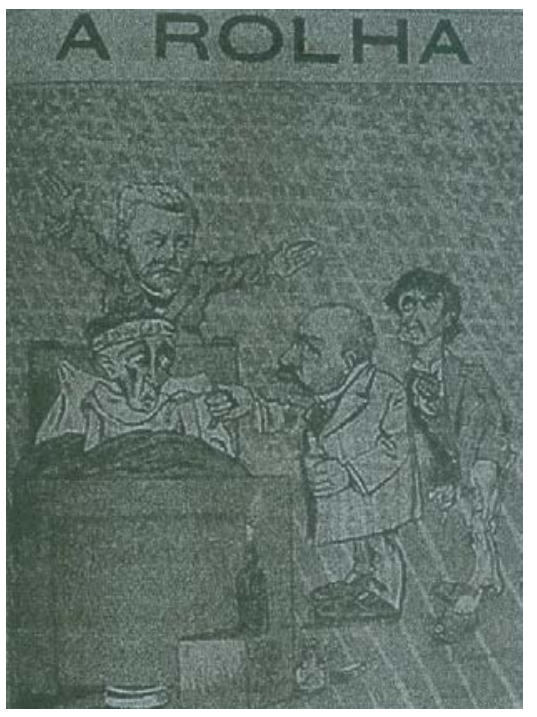

Xavier - Por Deus, doutor; não recorra a este extremo! (empréstimos) Lamenha - Mau! Não sendo assim a morte é inevitável. 
Zé - Quatro meses! Irra! Enquanto ela não se levantar hei de andar assim aos tropeções, esfarrapado pelos descontos.)

Fonte: O. Guimarães (1908).

A imagem de Zé foi construída, muitas vezes, na oscilação entre vítima e herói, transitando entre o homem comum e o mártir. Em uma das capas de $A$ Rolha (fig.12), a comemoração ao 21 de abril é usada para estabelecer proximidades entre o mártir da Independência e o mártir do cotidiano.

Figura 12 - A Rolha n. 3 - 23/04/1908 Zé (consternado).

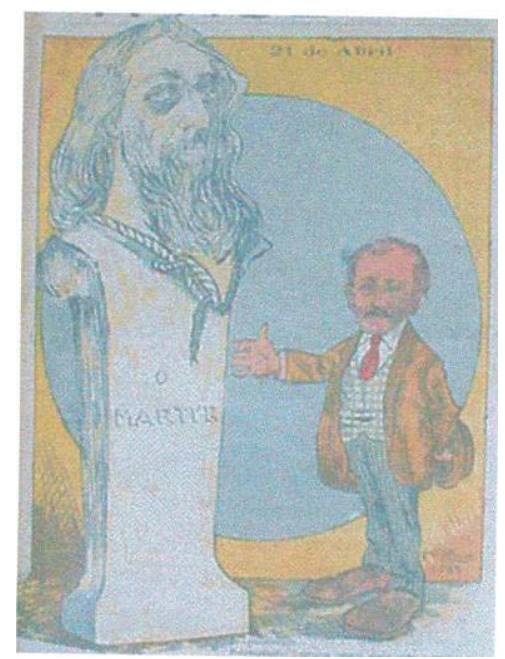

- Pobre coitado! Entregou com o maior ardor patriótico o seu prezado pescoço à corda infamante em holocausto da liberdade da Pátria, e hoje vemos sua obra grandiosa retalhada e enxovalhada!!!)

Fonte: Herônio (1908).

Sugere-se um paralelo entre o Zé e Tiradentes, nosso herói cívico mais popular. ${ }^{8}$

Heróis são símbolos poderosos, encarnações de ideias e aspirações, pontos de referência, fulcros de identificação coletiva. São, por isso, instrumentos eficazes para atingir a cabeça e o coração dos cidadãos a serviço da legitimação de regimes políticos [...] Herói que se preze tem de ter, de algum modo, a cara da nação. Tem de responder a alguma necessidade ou aspiração coletiva, refletir algum tipo de personalidade ou de comportamento que corresponda a um modelo coletivamente valorizado [...] (CARVALHO, 1990, p. 55).

${ }^{8}$ José Murilo de Carvalho (1990, p. 64) chama a atenção para o fato de que após a proclamação da República, aumentou o culto cívico a Tiradentes, havendo feriado nacional já em 1890, além da crescente associação à imagem de Cristo nas representações e descrições dele. 
Tiradentes é mostrado como um herói para se tirar o chapéu. O centro da composição é a mão de Zé, justamente no momento em que o aponta para nós. O círculo azul ao fundo, aberto no amarelo, lembra parte de nossa bandeira. Cria-se uma sugestão de contiguidade, que envolve Zé e Tiradentes, os inclui na mesma paisagem. Tiradentes não é nomeado, mas identificado pela corda, pela data, pela palavra mártir. Tornou-se um monumento. É representado por uma escultura em escala sobre-humana. $O$ pedestal é esculpido, expondo o volume e as características do mármore, contrastando com o efeito de esboço da cabeça, criado pelo desenho e pela textura de lápis, um herói inacabado, "mártir, integrador, portador da imagem do povo inteiro".(CARVALHO, 1990, p. 70).

O paralelismo da composição, colocando lado a lado duas verticais - Zé e Tiradentes unidas pela horizontal do braço de Zé, forma quase um $\mathrm{H}$, a visualização gráfica da primeira letra de herói. A palavra mártir, bem na direção para onde Zé aponta, estabelece comparações ente os dois, embora a estátua ultrapasse os limites do amarelo, alcançando o "R" do título e o Zé seja menor, enquadrado na cena.

O sentimento indicado no enunciado verbal - consternado - parece estar presente no olhar, no semblante de Tiradentes. Há um excesso de adjetivos, uma longa frase pra dizer que de sua obra, talvez, tenha restado apenas a estátua. E o desejo de ser livre:

[...] ele operava a unidade mística dos cidadãos, o sentimento de Participação, de união em torno de um ideal, fosse ele a liberdade, a independência ou a república. Era o totem cívico. Não antagonizava ninguém, não dividia as pessoas e as classes sociais, não dividia o país, não separava o presente do Passado nem do futuro. Pelo contrário, ligava a república à independência e a projetava para o ideal de crescente liberdade futura. A liberdade ainda que tardia". (CARVALHO, 1990, p. 68).

Mas há momentos em que Zé é apresentado como alguém que já perdeu as esperanças (fig.13). Numa capa de O Olho da Rua o vemos com um chapéu velho, aberto, com os sapatos furados, embora vestido a rigor, mesmo que em desalinho. Está arrumado com elegância para um encontro, levando uma coroa de flores. Zé vai prestar homenagem às esperanças, reverenciá-las. O gesto fino, delicado, triste e cansado, de humildade mesmo, contrapõe-se à austeridade, à força, ao jeito rude do coveiro, que, apoiado em sua ferramenta de trabalho, lança um olhar desconfiado, de estranhamento. O chapéu, a mão, as cruzes ao fundo e a coroa de flores formam uma vertical que divide a cena ao meio, criando uma nítida separação entre os dois: aquele que procura, que busca as esperanças e aquele que as esconde, enterra. Esta linha forma uma cruz com a linha do horizonte, o que, por outro lado, une os dois personagens, num jogo de falsa 
simetria, propondo as duas faces de um mesmo problema. A conformidade presente na expressão facial do Zé tem seu contraponto no rosto bem marcado do outro.

Figura 13 - O Olho da Rua n. 6 - 6/11/1909 "Finados"

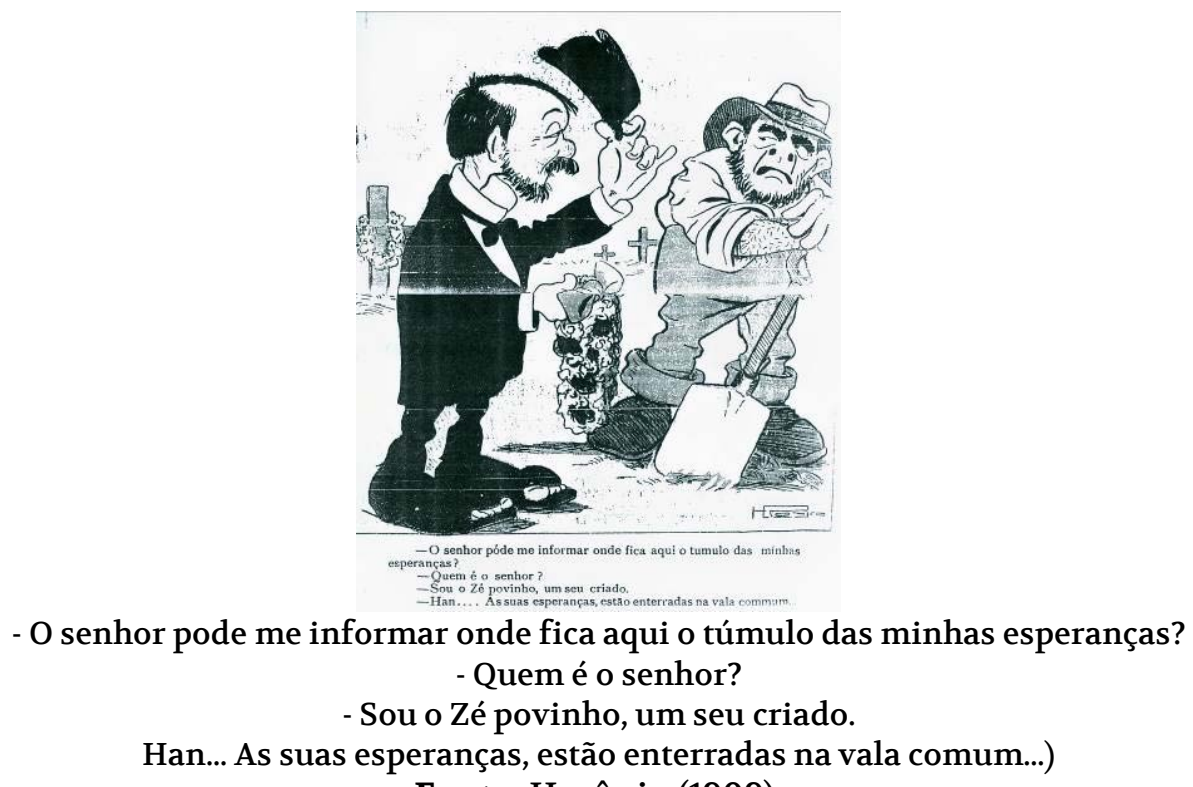

Fonte: Herônio (1909).

O que parece estar sendo sugerido é esse sentimento de perda, de ausência de algo que se faz presente pela memória e é revivido pela saudade: esperanças que se tomam lembranças. Lembrar é um modo de atuação, de manter-se presente e marcar essa presença. É uma tentativa de estabelecer uma comunicação com algo em que ainda se acredita, que ainda é amado. $O$ respeito aos mortos o leva a uma busca, talvez de si mesmo, talvez de outras esperanças e anseios jogados numa vala comum, de tantos outros zés. Como identificá-las? Ou serão as mesmas, unidas pelo mesmo destino? "E assim são todos os símbolos carnavalescos: estes sempre incorporam a Perspectiva de negação (morte) ou o contrário. $O$ nascimento é prenhe de morte, a morte, de um novo nascimento" (BAKHTIN, 1997, p. 125).

As reticências do discurso verbal criam o espaço do silêncio, insinuando uma espera. As relações de vida / morte, ausência / presença, esperança / desespero, conformidade / inconformidade, submissão / revolta, intensificam-se diante da morte. Presente, passado e futuro tornam-se simultâneos com a pura constatação da incerteza, no momento em que o "homem perdido e sem lugar - pode rir e festejar sua crise e morte através dos contrastes mais divergentes e estranhos" (PINHEIRO, 1994, p. 39). 


\section{Considerações}

Os caminhos que ligam o Zé Povinho português e os Zés curitibanos cruzam-se em impasses históricos: ambos convivem com processos de modernização, transição de regimes políticos, mudanças de paradigmas, mudanças nas artes, na arquitetura, na imprensa. Mantêm um diálogo constante com a arte, com a tradição da caricatura. Fazem parte do desejo de representar o povo, de fazê-lo presente nas mais diversas situações. Ambos são pobres, são vítimas, não detêm o poder. Mostram uma história pelo avesso, desdobrando e invertendo a ótica oficial.

Mas as diferenças também se entrelaçam. As imagens do Zé criado por Bordalo Pinheiro, analisadas aqui, nos remetem a um universo camponês, de um personagem que não fala, não se manifesta, está sempre parado, caracterizado da mesma forma, que precisa da presença de um narrador. Zé está sempre inserido dentro da cena, com o mesmo traje e os mesmos acessórios, em cenas que o ligam à terra. Mas ainda assim é deslocado, em situações ambíguas, que provocam questionamentos, pedem mudanças políticas e sociais. A riqueza do tratamento gráfico, valorizando a luz e a sombra, os volumes, é realçado pela textura da litografia, pelos traços cuidados e rigorosos, com um efeito de cores preciso. Tudo bem ao gosto do final do século XIX, misturando propostas acadêmicas e do art nouveau, ampliando as possibilidades de jogos entre figura e fundo.

No caso dos personagens brasileiros, os desenhos são mais estilizados, mais rápidos, na velocidade da imprensa diária e das novas técnicas de reprodução. Há uma ênfase no traço, na linha dos contornos. Personificavam as angústias, os assombros e o encantamento com os progressos técnicos, com o processo de modernização da Primeira República, sendo marcado pelos ritmos urbanos. Sua perplexidade assume características regionais, surgindo variações como o Zé Gaúcho, o Zé Paranaense, entre outros.

O Zé curitibano fala, dialoga, reflete, questiona, gesticula agitado, intromete-se nas questões político-administrativas, transita entre os lugares públicos e privados, estando próximo aos políticos, às autoridades, ora como participante, ora como observador, ora como vítima, ora como força política, rápido e ágil. Com o corpo forte para carregar os políticos às costas, algumas vezes enfraquecido como as finanças (fig.11); ou retorcido, esmagado pelas promessas da empresa de saneamento (fig.4); corpo inanimado como objeto decorativo (fig.8 e 9). Sua aparência varia tanto quanto seu ânimo e seus modos de presença. Humilde, esperto, tímido, exibido, com roupas remendadas, sapatos furados ou bem arrumado, sempre simples, convicto, incerto, decidido. É um personagem híbrido, denso, complexo. Foi colocado, muitas vezes, fora da cena, ou na marginalidade, porém, bem mais próximo do público, criando efeitos de subjetividade, de identificação. Não há o narrador mediando as questões. As falas, os gestos, os trejeitos são 
construídos como se o Zé representasse o próprio leitor. $\mathrm{O}$ enunciador faz crer ao enunciatário que ele é como o Zé Povo.

O caminho escolhido para marcar essas presenças do povo, para se representar o brasileiro em suas relações com o cotidiano, com o governo, com a sociedade do início do século $\mathrm{XX}$, foi a paródia, a construção carnavalizada e ambivalente desse "mundo às avessas".

Transitando entre o estereótipo, na medida em que tenta fixar ou generalizar um padrão, e o simulacro, representação que cria laços de semelhança com a realidade, acaba por descortinar a impossibilidade de se falar do povo como único e homogêneo. Entre o estranhamento e a proximidade, o hibridismo do personagem Zé Povo coloca em contato vários pontos de vista para sentir e compreender o mundo, buscando uma forma de mostrar esse cotidiano pela diversidade em que ele se constitui. Através de um "sistema de espelhos deformantes" que "alongam, reduzem e distorcem em diferentes sentidos e em diferentes graus" damo-nos conta da presença do outro, ainda que em seus reversos, pois "os contrários se encontram, se olham mutuamente, refletem-se um no outro, conhecem e compreendem um ao outro [...] Tudo em seu mundo vive em plena fronteira com o seu contrário." (BAKHTIN, 1997, p.127-179).

A construção da ideia de povo é elaborada não apenas como um "lugar de eterna frustração" (Silva, 1987, p. 95 ), mas como lugares de intersecção cultural, de mediação das várias instâncias sociais, de espaços múltiplos e tempos simultâneos de negociações.

A diversidade cultural, a heterogeneidade e a complexidade foram traçadas em múltiplos contornos, marcados pelos gestos, pelos diferentes sotaques, pelos erros da fala, pela indignação, pela ironia, pela descrença, pelo exibicionismo, pelos desejos e anseios, pela circulação dos tipos populares e pelas andanças de Zé Povo. As relações com o poder foram questionadas, removidas e aproximadas, diluídas no cotidiano, desenhando espaços de interação conflituosos entre o indivíduo e a sociedade.

\section{Bibliografia}

ARAUJO, Emanoel (org.) Rafael Bordalo Pinheiro - o português tal e qual: da caricatura a cerâmica. São Paulo: Pinacoteca do Estado, 1996.

BAKHTIN, Mikhail. Problemas da Poética de Dostoiévski. Trad. Paulo Bezerra. Rio de Janeiro: Forense Universitária, 1997.

BIRMINGHAM, David. A concise history of Portugal. London: Cambridge University Press, 1993.

BURKE, Peter. Testemunha Ocular: História e Imagem. Bauru: EDUSC, 2004 
CARNEIRO, Newton. O Paraná e a Caricatura. Curitiba: Grafipar, 1975

CARVALHO, José Murilo de. A formação das Almas. O imaginário da República no Brasil. São Paulo: Companhia das Letras, 1990.

CAVALCANTI, Lailson de Holanda. Historia del humor gráfico en el Brasil. Lleida: Editorial Milenio; Fundación Universidad de Alcalá, 2005.

CHALHOUB, Sidney; NEVES, Margarida de Souza; PEREIRA, Leonardo Affonso de Miranda.(org.) História em cousas miúdas. Campinas, SP: Editora da Unicamp, 2005

COSTA, Ângela Marques da \& SCHWARCZ, Lilia M. 1890-1914 - No tempo das certezas. São Paulo: Companhia das Letras, 2000.

DICIONÁRIO CONTEMPORÂNEO DA LÍNGUA PORTUGUESA CALDAS AULETE. Lisboa: Editora Delta, 1980.

DONALD, Diana. The age of caricature. Satirical prints in the reign of George III. London: Yale University Press, 1996

FONSECA, Joaquim da. Caricatura. A imagem gráfica do humor. Porto Alegre: Artes e Ofícios, 1999.

GARCIA CANCLINI, N. Hybrid Cultures. Strategies for Entering and Leaving Modernity. Trad. Chritopher L. Chiappari and Silvia L. Lopez. Minneapolis, University of Minnesota Press, 1995

GORDON, Ian. Comic Strips and Consumer Culture 1890-1945. London: Smithsonian Institution Press, 1998

GREIMAS, A . J. \& COURTES, J. Semiotics and Language. An Analytical Dictionary. Bloomington:Indiana University Press, 1982.

JANOVITCH, Paula Esther. Preso por trocadilho. A imprensa de narrativa irreverente paulistana 1900-1911. São Paulo: Alameda, 2006

LAGO, Pedro Corrêa do. Caricaturistas brasileiros. 1936-1999. Rio de Janeiro: Sextante Artes, 1999.

LANDOWSKI, Eric. A sociedade Refletida. Ensaios de sociossemiótica. Trad. Por Eduardo Brandão. São Paulo: EDUC/Pontes, 1992

LANDOWSKI, Eric. Não se brinca com humor: a imprensa política e suas charges. In: FACE. São Paulo: EDUC, 4(2):64-95, jul/dez.1995

LANDOWSKI, Eric. Presenças do Outro. São Paulo: Editora Perspectiva, 2002.

LEMOS, Renato (org.) Uma história do Brasil através da caricatura. Rio de Janeiro: Bom Texto, Letras e Expressões, 2001.

LIMA, Herman. História da Caricatura no Brasil. Rio de Janeiro: J. Olympio, 1963. 
MARTINS, Ana Luiza. Revistas em revista. Imprensa e práticas culturais em tempos de República, São Paulo (1890-1922). São Paulo: Ed. Da Universidade de São Paulo: Fapesp: Imprensa Oficial do Estado, 2001

MEARLEAU-PONTY, M. Body as expression and speech. In FISHER, Alden. L. The essential writings of Mearleau-Ponty. New York: Harcourt, Brace \& World, 1969, p.185-213.

OLIVEIRA, Ana Claudia M. As semioses pictóricas. In: FACE. São Paulo: EDUC, 4(2): 104-145, jul/dez.1995

PADILHA, Márcia. A cidade como espetáculo. Publicidade e vida urbana na São Paulo dos anos 20. São Paulo: Annablume, 2001

PESAVENTO, Sandra Jatahy. Porto Alegre Caricata: a imagem conta a história. Porto Alegre, EU/Secretaria Municipal da Cultura, 1993.

PINHEIRO, Amalio. Aquém da Identidade e da Oposição. Formas na cultura mestiça. Piracicaba: Unimep, 1994

QUELUZ, Marilda L. P. Traços Urbanos. São Paulo: PUC-SP, tese de doutorado, 2002.

RAGO, Margareth. Do cabaré ao lar. A utopia da cidade disciplinar. Brasil: 1890-1930. Rio de Janeiro: Paz e Terra, 1985.

RIBEIRO, Pedro Krause. Memórias do Zé Povo ou memórias individuais? O povo na retórica da charge e a legitimação dos discursos políticos dos caricaturistas na imprensa carioca do início do século XX. In Anais XIV Encontro Regional da ANPUH-RIO - Memória e Patrimônio. Rio de Janeiro, 2010, pp. 01-09. Disponível em <http://www.encontro2010.rj.anpuh.org/resources/anais/8/1276642118_ARQUIVO_PedroKrause. pdf $>$ Acesso em 22/02/2011

RIBEIRO, Pedro Krause. O "povo" na retórica da charge: Zé Povinho e Zé Povo na imprensa lusobrasileira (1875-1907) in Anais do II Encontro Nacional de Estudos da Imagem. Londrina: UEL, 2009, pp.1037-1046. Disponível

<http://www.uel.br/eventos/eneimagem/anais/trabalhos/pdf/Ribeiro Pedro\%20Krause.pdf> Acesso em 22/02/2011.

RIVERS, Kenneth T. Transmutations. Understanding Literary and Pictorial Caricature. Lanham, Maryland: London: University Press of America, 1991.

SALIBA, Elias Thomé. A dimensão cômica da vida privada na República. In SEVCENKO, N. org. História da Vida Privada no Brasil. República: da Belle Époque à Era do Rádio. São Paulo: Companhia das Letras, 1998

SALIBA, Elias Thomé. Raízes do riso. A representação humorística na história brasileira: da belle époque aos primeiros tempos do rádio. São Paulo: Companhia das Letras, 2002

SARDUY, Severo. Barroco. Trad. Maria de Lourdes Júdice e José Manuel de Vasconcelos. Lisboa: Veja, 1988. 
SILVA, Marcos A. da. Caricata República. Zé Povo e o Brasil. São Paulo: Marco Zero, 1987.

SOUSA, Osvaldo Macedo de. Historia del humor gráfico em Portugal. Lleida: Editorial Milenio, 2002.

SUSSEKIND, Flora. Cinematógrafo de Letras: literatura, técnica e modernização no Brasil. São Paulo: Companhia das Letras, 1987.

VELLOSO, Mônica Pimenta. Modernismo no Rio de Janeiro. Rio de Janeiro: Editora Fundação Getúlio Vargas, 1996

Recebido em 30/02/2012

Aprovado em 30/05/2012 